\title{
DEVELOPING ENGLISH LISTENING MATERIALS FOR THE TENTH GRADE STUDENTS OF TOURISM MAJOR IN VOCATIONAL SCHOOL
}

\author{
ARTICLE \\ Submitted as a Partial Fulfillment of the Requirements for \\ the Degree of Sarjana Pendidikan
}

By:

SIMON CHRISTOFEL SILALAHI

Registration Number: 2123121051

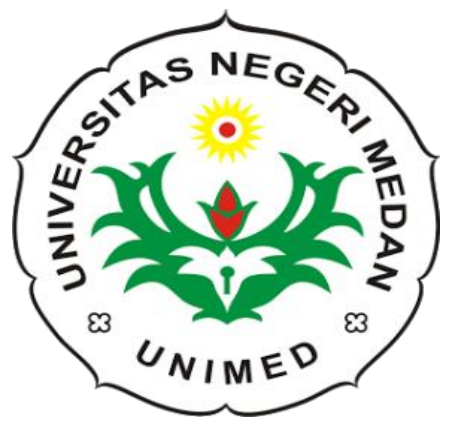

ENGLISH AND LITERATURE DEPARTMENT

FACULTY OF LANGUAGE AND ARTS STATE UNIVERSITY OF MEDAN 2017 
ARTIKEL

\title{
DEVELOPING ENGLISH LISTENING MATERIALS FOR THE TENTH GRADE STUDENTS OF TOURISM MAJOR IN VOCATIONAL SCHOOL
}

\author{
Disusun dan Diajukan oleh: \\ Simon Christofel Silalahi
}

NIM. 2123121051

Telah diverifikasi dan dinyatakan memenuhi syarat

Untuk diunggah pada jurnal online

Medan, April 2017

Menyetujui

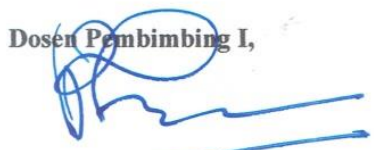

Dr. Bahmad Husein, M.Ed. NIP. 196206291988031002

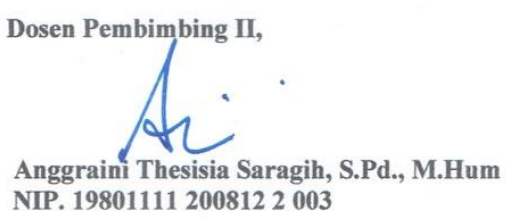

Dosen Pembimbing II, NIP. 198011112008122003

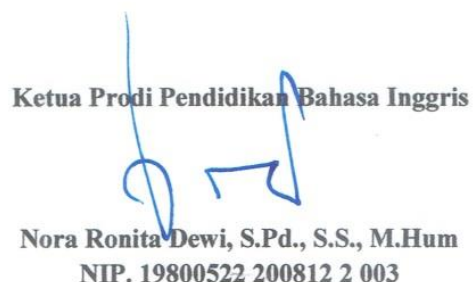




\title{
DEVELOPING ENGLISH LISTENING MATERIALS FOR THE TENTH GRADE STUDENTS OF TOURISM MAJOR IN VOCATIONAL SCHOOL \\ "Simon Christofel Silalahi \\ *** Rahmad Husein \\ ** Anggraini Thesisia Saragih
}

\begin{abstract}
Silalahi, Simon Christofel. Registration Number: 2123121051. Developing English Listening Materials for the Tenth Grade Students of Tourism Major in Vocational School. English Education Study Program, State University of Medan, 2017.

The objective of this study is to find out what the English listening materials are appropriate for students in tourism major. Indonesia has many spots for tourism then it makes government to improve the students' ability in tourism major. Since the students need to communicate with other people especially tourist then it needs to improve listening skill. Because basically listening is a skill of English that consists of receiving, constructing, and responding to verbal or nonverbal massage. In fact, the finding of materials that provided for the Grade X students of Tourism major at SMK Negeri 7 Medan that listening materials provided in the textbook are not related to the students' major. Then it is needed to develop the English listening materials for the tenth grade of tourism major. The research was conducted by using Research and Development (R\&D) method. The subject of this research was 2016/2017 students of the tenth grade of tourism major in SMK Negeri 7 Medan. The number of the students was 26 students. The data of this study were collected by using need analysis questionnaire, and interview. It was found that $61.90 \%$ of the respondents assumed that existing listening materials are not related to their major, and $93.75 \%$ expected major-related English listening materials. The experts' validation shows that the developed listening materials are appropriate and recommended to be used. At the end of this study, teachers are expected to be able to see the students' needs and can prepare even develop the materials in order to meet students' needs and job.
\end{abstract}

Key words: Research and Development, English listening materials, Tourism

\footnotetext{
${ }^{*}$ Graduate Status

${ }^{* *}$ Lecturer Status
} 


\section{INTRODUCTION}

\section{Background of the Study}

In Indonesia, English is utilized as a foreign language and plays important roles in education. English become one of subjects to be examined to get higher education level. English is also used as the access to gain the knowledge and information through World Wide Web.

Sekolah Menengah Kejuruan (SMK) or Vocational School is kind of education in Indonesia besides senior high school. The difference is vocational school prepares their students to get ready for work after they finish their study. Besides their skills, they also can use English to get better job later.

Listening is a language skill that enables human to get the message from what being heard. Listening is important because it is a skill of English that consists of receiving, constructing, and responding to verbal or nonverbal message (Verderber, et al : 2008). Thus, before people can speak and build communicate well, they should listen the others.

Moreover, listening skill becomes one of the skills that should be mastered since it is a part of National Examination. Students have to listen carefully while the record is playing. They need to gain the message from what is being said by the speaker and then they need to write down the message on their paper test. Unfortunately it is hard for the students who do not have good lesson in their school due to the material which taught at school are not suitable with their major.

Unfortunately, mostly teacher are ignored the problem that faced by the students. They just skip listening section and move to the next lesson without finish the listening section. In fact, teacher should know the factors that influence the achievement of student while doing the listening section such as irrelevant materials, teaching strategy, and failure in managing students' motivation. 
Based on the explanations, it is an important thing then to review the listening materials for the Grade X students of tourism major, then to develop these listening materials which related to the students' major in order to help improving the students' learning eagerness and to improve their mastery on listening skill to achieve the competency standards moreover it will help them to get work later since they are students of vocational school.

\section{REVIEW OF LITERATURE}

Listening is a receptive skill that allows people communicate each other. Rost (2002:2) describes listening in its broadest sense as a process of receiving what the speakers actually says, constructing and representing meaning, negotiating meaning with the speakers and responding, and creating meaning through involvement, imagination and empathy. Means, listening is not just about sound, intonation, and words but it is complex skill which runs in real activity. Listeners should be active and creative in catching the message or content of the information. Further, Brown (2001:247) describes listening as a major component in language learning and teaching. This is to say that listening plays a important role in learning especially for communicating.

Learning materials is important as a media for students to get the lesson from teacher. Learning material can be defined as any materials used by the teacher and students for teaching and learning process. Learning material should help students get the essence of learning process. Like Tomlinson (2008:4) said that learning materials should provide opportunities for feedback. Unfortunately, teachers nowadays have not aware about the learning materials that used in learning process. They just used the textbook as the main learning material in every learning process. In fact, Tomlinson (2001:66) explains "material is anything which is used to help to teach language to the students. Material can be in the form of a textbook, a workbook, a cassette, a CD-ROM, a video, a photocopied handout, a newspaper, a paragraph written on a whiteboard: anything which present or informs about the language being 
learned. In the other words, teacher can develop the learning material based on students' needs.

ESP has emerges as one of the major areas of EFL teaching today. Hutchinson and Waters (1986:19) who state " ESP is an approach to language teaching in which all decisions as to content and method are based on the learner's reason for learning. ESP aims to make students know where they can use the English after they finish their learning process. In line with that, Basturkmen (2010:8) said that in ESP the learner is seen as a language learner engaged either in academic, professional or occupational pursuits and who uses English as a means to carry out those pursuits.

Indonesia's National Education Department by the Letter of Decision Number 7013/D/KP/2013 about the Competences Spectrum on Vocational School have specified that there are 6 competency major in vocational school, namely: (1) Technology and Engineering, (2) Information and Communication Technology, (3) Health, (4) Agribusiness and Agro technology, (5) Fisheries and Marine, (6) Business and Management, (7) Tourism, (8) Art and Craft, and (9) Performing Arts. Tourism competency major then is subdivided into Kepariwisataan, Tata Boga, Tata Kecantikan, dan Tata Busana. The major Kepariwisataan then divided into travel agency and hotel accommodation.

\section{RESEARCH METHODOLOGY AND FINDINGS}

Methodology

The research was conducted by using the educational research and development (R \& D) proposed by Borg and Gall. Based on Borg and Gall (2003:569) R \& D is "an industry-based development model in which the findings of research are used to

design new products and procedures, which then are systematically field-tested, evaluated, and refined until they meet specified criteria of effectiveness, quality, or similar standards.” R \& D contains ten stages during the research, namely: Research 
and Information Collecting, Planning, Development of Preliminary Form of Product, Preliminary Field Testing, Main Product Revision, Main Field Testing, Operational Product Revision, Operational Field Testing, Final Product Revision, and Dissemination and Implementation (Borg \& Gall, 1983:775).

Borg and Gall (2003:572) explained that: "it is highly unlikely a graduate student will be able to find the financial and personnel support to complete a major $\mathrm{R}$ \& D project... If you plan to do an $\mathrm{R} \& \mathrm{D}$ project for a thesis or dissertation, you should keep these cautions in mind. It is best to undertake a small-scale project that involves a limited amount of original instructional design...Another way to scale down the project is to limit development to just a few steps of the R \& D cycle.” By considering these statements, only five stages applied in order to solve the problem in this study because of the limited time, capacity and financial. This reduction of stages of R \& D then called by Borg and Gall as "Small-Scale R \& D Project"..

\section{Procedures of Materials Development}

This research was conducted by adapting the Small-Scale R \& D Project proposed by Borg and Gall, which are as follows:
a. Research and information collecting
b. Planning
c. Develop preliminary form of product
d. Preliminary field testing
e. Main product revision

\section{Findings}

\section{Research and information collecting}

The existing materials are in the form of textbook entitled Bahasa Inggris SMAMA/SMK Kelas X Wajib by Otong Setiawan Dj. The topics of the materials for one 
semester are provided below. These topics of the existing materials then developed by considering the students' needs.

Table 1 Topics in Existing Listening Materials

\begin{tabular}{|c|c|}
\hline Chapter & Title \\
\hline $\mathbf{1}$ & Can I Have Your Name, Please? \\
\hline $\mathbf{2}$ & Excellent! \\
\hline $\mathbf{3}$ & Are You OK? \\
\hline $\mathbf{4}$ & I'd Like To.... \\
\hline $\mathbf{5}$ & Congratulations \\
\hline $\mathbf{6}$ & Have You Ever Tried It? \\
\hline
\end{tabular}

(From: Bahasa Inggris SMA-MA/SMK Kelas X Wajib, Otong Setiawan Dj)

In order to fit to the research on appropriate English listening materials then some criteria which are provided by Wong (2014) is amended. The criteria can be seen as following;

Table 2 Criteria for English Listening by Wong (2014)

\begin{tabular}{|c|}
\hline CRITERIA \\
\hline LINGUISTIC CONTENT \\
\hline $\begin{array}{l}\text { The range of vocabulary is wide by covers tourism terminologies which are } \\
\text { useful enough for students majoring in tourism }\end{array}$ \\
\hline The listening materials are authentic \\
\hline The listening tasks are realistic and related to tourism field \\
\hline Examples and texts are correctly written \\
\hline $\begin{array}{l}\text { There are activities designed for integrating language skills in relation to } \\
\text { tourism field }\end{array}$ \\
\hline The materials is relevant and consistent \\
\hline There is a glossary in tourism field \\
\hline $\begin{array}{l}\text { The listening activities are designed to guide learners to answer questions } \\
\text { related to the activities }\end{array}$ \\
\hline $\begin{array}{l}\text { OTHER CONTENT } \\
\end{array}$ \\
\hline The situation in the audio is authentic \\
\hline The intonation of the audio is appropriate \\
\hline $\begin{array}{l}\text { The content is combined with a series of pictures of tourism that facilitate } \\
\text { learners' listening activities }\end{array}$ \\
\hline The language and content of the audio are used in authentic situations \\
\hline $\begin{array}{l}\text { Text, images, and sounds are appropriately coordinated to the situation } \\
\text { (e.g., reservation language is presented with suitable conversation and } \\
\text { relevant pictures) }\end{array}$ \\
\hline
\end{tabular}




\begin{tabular}{|l|}
\hline Written aids are provided for audio (e.g., scripts of listening activities) \\
\hline $\begin{array}{l}\text { Audio are provided with different accents (e.g., British, American, } \\
\text { Australian, Canadian) }\end{array}$ \\
\hline Clear instruction are provided in the audio \\
\hline \multicolumn{1}{|c|}{ LEARNER CONCERNS } \\
\hline The textbook fits target needs in tourism field \\
\hline $\begin{array}{l}\text { Learner are provided with opportunities to interact with different types of } \\
\text { learning content }\end{array}$ \\
\hline Different levels (difficulty of activities) of listening materials are provided \\
\hline The listening activities can increase learners' interaction \\
\hline $\begin{array}{l}\text { Learners perceive the textbook as interesting, useful and relevant to the } \\
\text { tourism major }\end{array}$ \\
\hline $\begin{array}{l}\text { There are references, websites, and additional resources for students to try } \\
\text { on their own }\end{array}$ \\
\hline $\begin{array}{l}\text { Activities can allow the learners to transfer some of the information they } \\
\text { hear (e.g., draw a picture, write key words) }\end{array}$ \\
\hline \multicolumn{2}{|c|}{ PRACAL CONCERNS } \\
\hline The textbook is affordable \\
\hline The textbook is easy for students to carry \\
\hline The textbook is attractive \\
\hline The textbook is durable \\
\hline The textbook is easy on the eyes \\
\hline The textbook provides an Audio CD \\
\hline
\end{tabular}

The research was continued by doing needs analysis of the learners by administering the questionnaires.

The students were asked about the generality of the existing materials, the Table 3 below shows the result.

Table 3 Students' Judgment on Existing Listening Materials

\begin{tabular}{|l|l|c|}
\hline \multicolumn{1}{|c|}{ Question } & \multicolumn{1}{|c|}{ Scale } & Percentage \\
\hline $\begin{array}{l}\text { Listening materials } \\
\text { provided in our learning } \\
\text { materials are ... }\end{array}$ & Not Related to my major & $61.90 \%$ \\
\cline { 2 - 3 } & Related to my major & $38.10 \%$ \\
\hline
\end{tabular}

Then the intention to develop the materials is supported by this finding. it is also important to see how this decision meets the students' need. This following table shows the result of needs analysis whether students need developed materials or not. 
Table 4 Students' Needs of Major-related Listening Materials

\begin{tabular}{|l|l|c|}
\hline \multicolumn{1}{|c|}{ Question } & \multicolumn{1}{|c|}{ Scale } & Percentage \\
\hline $\begin{array}{l}\text { In developing English } \\
\text { listening materials which } \\
\text { are related to my major, I } \\
\text { would ... }\end{array}$ & Agree & $93.75 \%$ \\
\cline { 2 - 3 } & Disagree & $6.25 \%$ \\
\hline
\end{tabular}

The Tables 3 and 4 above show the respond which positively support this research was that students are mostly want their listening materials should be related to their major

\section{Planning}

After the results of a needs analysis had been got then it had been compared with vocational school syllabus for the English subject. The development of listening material had been begun to be planned. In this case, planning and designing the draft of suitable listening materials for use in listening activities has done. In the planning process, existing materials were also used for consideration in developing the listening material.

\section{Development of Preliminary Form of Product}

By having a base on the result of needs analysis the researcher has developed the existing listening materials as the final draft. Below is the existing materials compared with the develop materials' final draft of Chapter 1. 


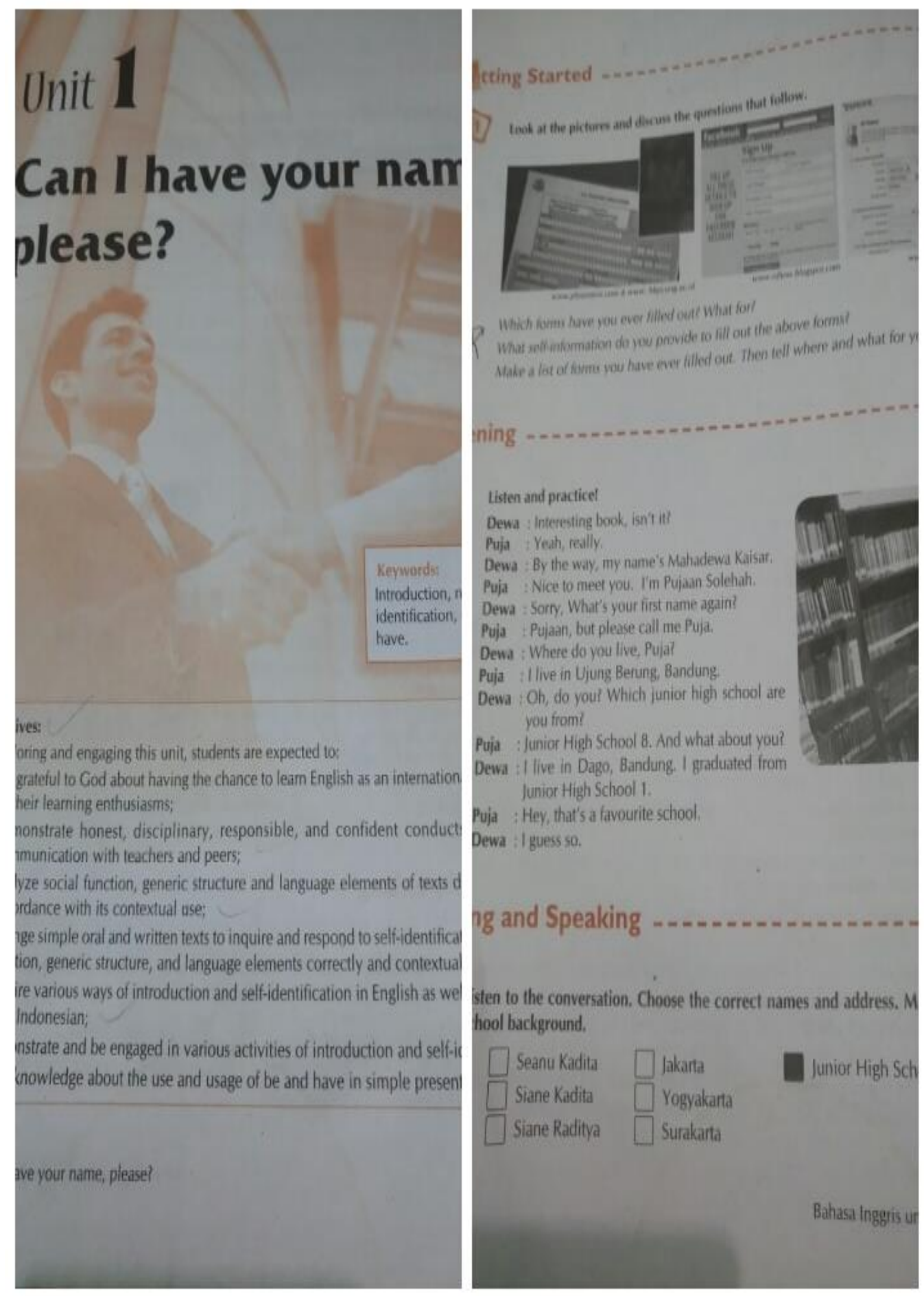

\section{(Chapter 1 in the existing materials)}


Chapter 1 in the developed materials:

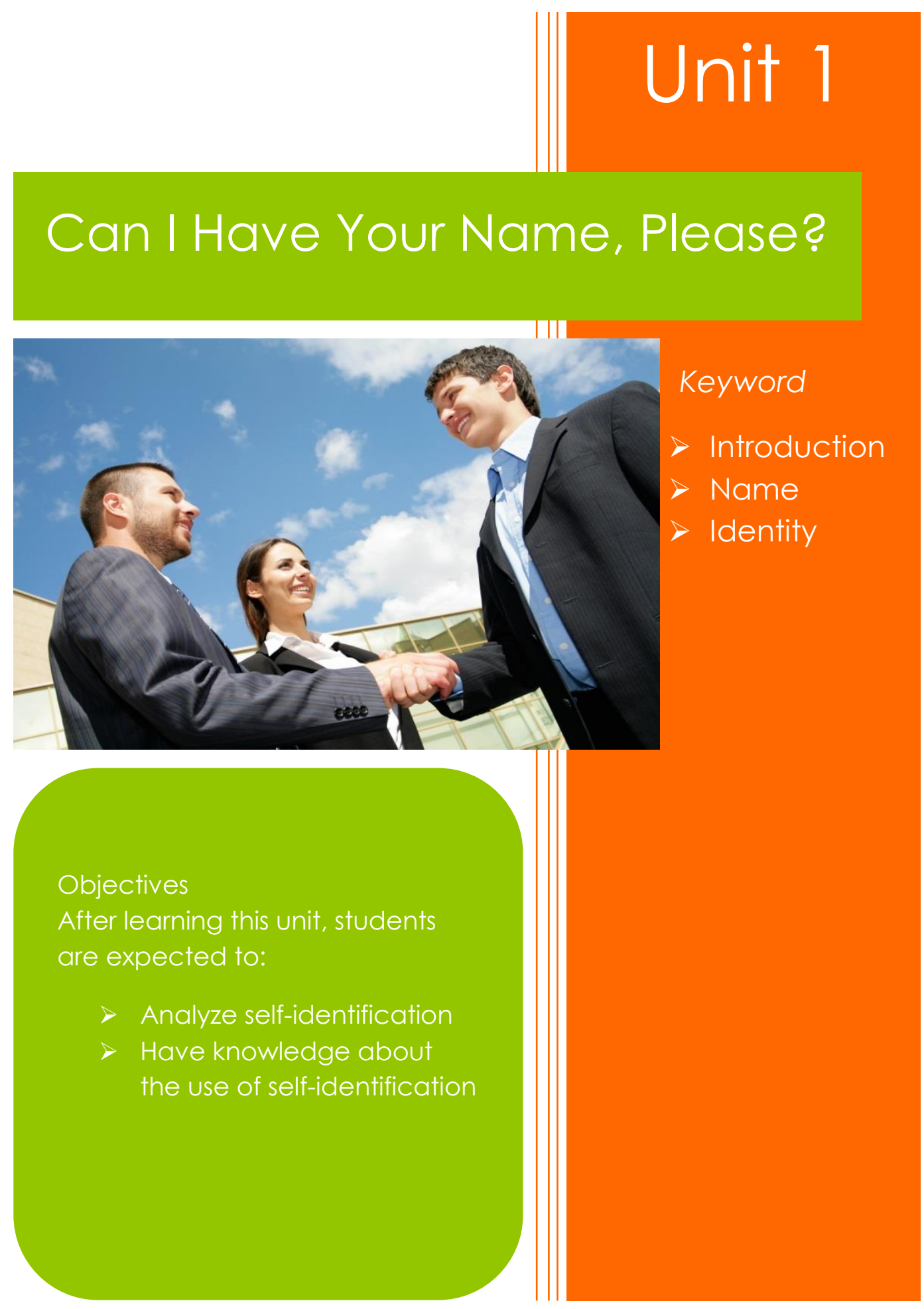




\section{Listening.............................1}

\section{A A G}

Listen and complete the dialog!

Ucok : Hello, good morning!

Butet : Good morning sir, may I help you?

Ucok : I'd like to ___ a flight to Medan please.

Butet : Can I have your name, sir?

Ucok : Sure, I'm Ucok

Butet : Ok Mr. Ucok, which would you like to use?

Ucok : Which is the cheapest?

Butet : When do you want to go?

Ucok : Next week, the $15^{\text {th }}$

Butet : Would you like a

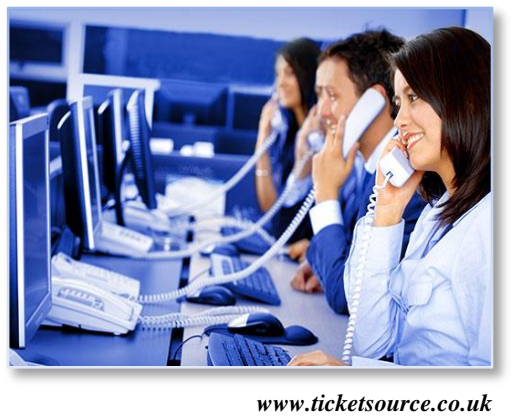
?

Ucok : Yes, I'm coming back on the $30^{\text {th }}$

Butet : Let me see.... Lion Air costs Rp.3.000.000, but you have to at Batam. Garuda Air is the cheapest at Rp.4.000.000, both tourist class of course.

Ucok : How long does the Lion flight take?

Butet : Total time is 15 hours, Garuda takes 11 hours

Ucok : I'm going to take Garuda flight then.

Butet : How many __ would you like?

Ucok : Just one, and could I have a vegetarian meal?

Butet : Certainly, There's no extra charge.

Listen to the conversation. Choose the correct names and address. Make corrections to the school background.

1.

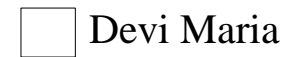

Devi Maria

Siantar

Junior High School 2 
Devi Marita

Davie Maritya

2. $\square$ Andre Mario

Andrey Maria

Audrey Marion

3. $\square$ Yosua Purbay

Josua Purba

Josua Purna $\square$ Medan

Samosir

Kisaran

Balige

Aceh

Parapat

Senior High School 2

Siantar

Pakam

Listen to two conversations. Check the cities the people talk about.

$\begin{array}{ll}\square \text { Ambon } & \square \text { Bandung } \\ \square \text { Medan } & \square \text { Kuningan } \square \text { Jakarta } \\ & \\ \square \text { Sleman } & \square \text { Padang } \\ \end{array}$

Listen again. Answer the questions.

1. What is Ucok's nick name?

2. Where is Ucok from?

3. Where does Maria come from?

4. What's Andriyani's last name?

5. Where is Andriyani from?

6. Where does Andriyani go to school? 


\section{Compact Dictionary}

book: memesan

return ticket: tiket pulang pergi

one way ticket: tiket sekali jalan

seat: tempat duduk

picking up: menjemput

reassigned: dipindahtugaskan

direct flight: penerbangan langsung

landmark: hal yang menonjol (tempat) cheapest: paling murah

just moved: baru pindah

both: keduanya

certainly: pasti

drop off: menurunkan

crowd: ramai

build: membangun

\section{Preliminary Field Testing}

The preliminary field testing was done after checking the final draft. Then, one of the materials was tested that have been developed to the Grade X students of SMK Negeri 7 Medan. The tested listening material is on Unit 5 Activity 2 of the developed listening materials. The result then also compared equally to the existing listening material on the same part, Unit 5 Activity 3 on page 59.

The result is as can be seen in Table 7 below:

Table 7 Preliminary Field Test Result for Existing Listening Materials

\begin{tabular}{|c|l|c|c|}
\hline No. & Respondent's Initials & $\begin{array}{c}\text { Correct } \\
\text { Answer }\end{array}$ & $\begin{array}{c}\text { Score } \\
(\text { CA } \times \mathbf{1 0} \text { points })\end{array}$ \\
\hline 1. & ES & 8 & 80 \\
\hline 2. & SM & 8 & 80 \\
\hline 3. & MIS & 3 & 30 \\
\hline 4. & AS & 9 & 90 \\
\hline 5. & AMS & 7 & 70 \\
\hline \multicolumn{2}{|r|}{} \\
\hline
\end{tabular}

Some mistakes were found in the students' answer sheets for the developed listening materials: (1) choose wrong answer; and (2) did not answer. 
The result of the preliminary field test of the developed listening materials is as described in Table 8.

Table 8 Preliminary Field Test Result for Developed Listening Materials

\begin{tabular}{|c|l|c|c|}
\hline No. & Respondent's Initials & $\begin{array}{c}\text { Correct } \\
\text { Answer }\end{array}$ & $\begin{array}{c}\text { Score } \\
(\mathbf{C A} \times \mathbf{1 0} \text { points })\end{array}$ \\
\hline 1. & ES & 9 & 90 \\
\hline 2. & SM & 8 & 80 \\
\hline 3. & MIS & 5 & 50 \\
\hline 4. & AS & 8 & 80 \\
\hline 5. & AMS & 9 & 90 \\
\hline \multicolumn{2}{r}{} \\
\hline
\end{tabular}

Some mistakes were found in the students' answer sheets for the developed listening materials: (1) choose wrong answer; and (2) did not answer.

\section{Main Product Revision}

The main product, which is developed listening materials, has been validated by experts to check the components of the developed materials based on some specified criteria. The validating instrument consists of 4 criteria of validity, which are linguistics, process, product and content, and layout.

The researcher group the percentage of the validation score into 5 groups as follow:

$$
\begin{aligned}
\text { Very good/relevant/appropriate } & =81-100 \% \\
\text { Good/relevant/appropriate } & =61-80 \% \\
\text { Fair } & =41-60 \% \\
\text { Less relevant/appropriate } & =21-40 \% \\
\text { Very less relevant/appropriate } & =0-20 \%
\end{aligned}
$$

The experts were one lecturer of English Department at State University of Mean and the English teacher at SMK Negeri 7 Medan.

The first validator is Rafika Dewi Nasution, S.Pd., M.Hum., who is a lecturer of English Education program at State University of Medan mastering in Listening. The validation result is provided in Table 9: 
Table 9 The Validation Result of Validator I

\begin{tabular}{|c|l|c|c|}
\hline No. & \multicolumn{1}{|c|}{ Criteria } & Maximum Score & $\begin{array}{c}\text { Total Given } \\
\text { Score }\end{array}$ \\
\hline 1. & Linguistics & 40 & 34 \\
\hline 2. & Process & 30 & 25 \\
\hline 3. & Product and Content & 45 & 37 \\
\hline 4. & Layout & 35 & 31 \\
\hline \multicolumn{2}{r|}{ Total } & $\mathbf{1 5 0}$ & $\mathbf{1 2 7}$ \\
\hline \multicolumn{2}{|c|}{ Percentage } & $(127 / 150) \times 100 \%=\mathbf{8 4 . 6 6 \%}$ \\
\hline
\end{tabular}

From the formulation of the validation sheet, Validator I gave the total score of $84.66 \%$ which means that the developed listening materials are very relevant. She also gave some comments as following:

- Linguistics: standardize the use and accuracy of grammar is good

- Process: listening materials in the learning process is already good

- Product and content: content still need to be supplemented from other sources, so as to create an update learning materials.

- Layout: in general, dimensional appearance of the layout is good.

The second validator is Drs. Robert Pardede, the English teacher at SMK Negeri 7 Medan. The validation result is provided in the following Table 10:

Table 10 The Validation Result of Validator II

\begin{tabular}{|c|l|c|c|}
\hline No. & \multicolumn{1}{|c|}{ Criteria } & $\begin{array}{c}\text { Maximum } \\
\text { Score }\end{array}$ & $\begin{array}{c}\text { Total Given } \\
\text { Score }\end{array}$ \\
\hline 1. & Linguistics & 40 & 37 \\
\hline 2. & Process & 30 & 27 \\
\hline 3. & Product and Content & 45 & 41 \\
\hline 4. & Layout & 35 & 32 \\
\hline & Total & $\mathbf{1 5 0}$ & $\mathbf{1 3 7}$ \\
\hline \multicolumn{2}{r|}{ Percentage } & $(137 / 150) \times 100 \%=\mathbf{9 1 . 3 3 \%}$ \\
\hline
\end{tabular}

From the formulation of the validation sheet, Validator II gave the total score of $91.33 \%$ which means that the developed listening materials are very relevant. He also gave some comments as following:

- Linguistics: the use and suitability of grammar is already good.

- Process: the materials presented already meet the standard.

- Product and content: to be more adapted to the major's terminology. 
- Layout: Layout is good.

Finally, final steps of this research, based on these validation results done by the validators, these listening materials are appropriate and recommended by the researcher to be used by the Grade X students of Tourism Major of SMK Negeri 7 Medan

\section{CONCLUSION AND SUGGESTIONS}

Conclusions

As for conclusion of this study, Students know about the importance of English for their life moreover they are from tourism major which is need to meet people (tourist) to communicate with them. Besides, the demands of the market also need the students to know much more about the terminology of tourism. So, students expect they can get listening material related to their major and their needs, which is also equipped with interactive media. Hence, the learning process can motivate them to improve their listening ability to meet market demand. By considering those statements, developing English listening materials which is relevant to the students' needs is needed.

\section{Suggestions}

Researcher suggests the stakeholder which they are teacher and students should be able to use and develop learning materials based on the students' needs and major and be aware of the demand for the scope of work, so they can work together with teacher to improve their skills.

For other researcher, it is highly suggested to other researchers to conduct studies on developing listening materials to students of vocational school to find out the most appropriate listening materials which are related to their major and needs. 


\section{REFERENCES}

Basturkmen, H. (2010). Developing Courses in English for Specific Purposes. New York: Palgrave Macmillan.

Borg, W. R., \& Gall, M. D. (1983). Educational Research An Introduction Fourth Edition. New York: Longman.

Brown, H. D. (2001). Teaching by Principles, An Interactive Approach to Language Pedagogy, Second Edition. London: Longman.

Gall, M. D., Gall, J. P., \& Borg, W. R. (2003). Educational Research An Introduction Seventh Edition. Boston: Ablongman

Hutchinson, T, \& Waters, A. (1986). English for Specific Purposes: A Learningcentered Approach. Cambridge: Cambridge University Press.

Menteri Pendidikan dan Kebudayaan. (2013). Keputusan Direktur Jenderal Pendidikan Menengah Kementerian Pendidikan dan Kebudayaan Nomor: 7013/D/KP/2013 tentang Spektrum Keahlian Pendidikan Menengah Kejuruan.

Rost, M. (2002). Teaching and Researching Listening. Edinburgh Gate, England: Pearson Education.

Tomlinson, B. (2001). Materials development. In Ronald Carter \& David Nunan (Ed.), The Cambridge Guide to Teaching English to Speakers of Other Languages (pp. 66-71). Cambridge University Press

Tomlinson, B. (2008). Language Acquisition and Language Learning Materials. In Brian Tomlinson (Ed.), English Language Learning Materials: A Critical Review (pp. 3-13). London: Continuum

Verderber, R. F., et.al. (2008). The Challenge of Effective Speaking. USA: Thomson Wadsworth

Wong, Ruth M. H. (2014) Developing Criteria for Textbook Evaluation. TESL Reporter, $42 \quad$ (1), 52-57. Retrieved from: https://journals.lib.byu.edu/spc/index.php/TESL/ 